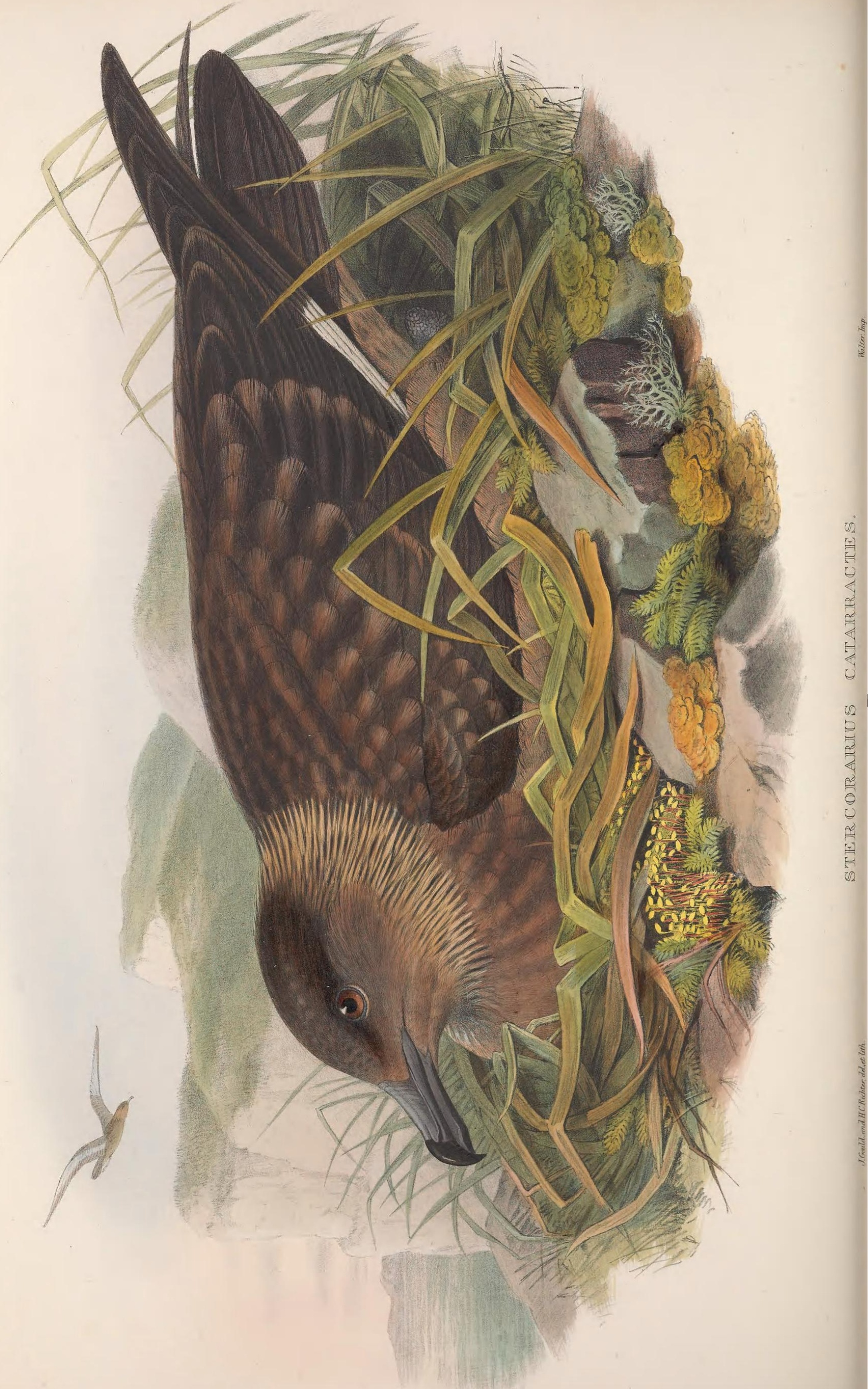




\section{STERCORARIUS CATARRHACTES.}

\section{Great Skua.}

Larus Catarrhactes, Linn. Syst. Nat., tom. i. p. 226.

fuscus, Briss. Orn., tom. vi. p. 165.

Lestris catharractes, Ill. Prod. Syst. Mamm. et Av., p. 273.

Catharacta Skua, Brünn. Orn. Bor., no. 125.

Cataractes vulgaris, Flem. Edinb. Phil. Journ., vol. i. p. 97.

Catarractes skua, Steph. Cont. Shaw's Gen. Zool., vol. xiii. p. 215.

Catarractes noster, Sibb. Scot. Illust., vol. ii. p. 20, pl. 14. fig. 1.

Stercorarius catarrhactes, Gray and Mitch. Gen. of Birds, vol. iii. p. 653, Stercorarius, sp. 5 .

Lestris antarctica, Less. Traité d'Orn., p. 616.

Megalestris catarractes, Bonap. Consp. Av. 1856, p. 206.

THIs is the largest species of a group of sea-birds distinguished for many peculiarities in their habits and economy, and to which the generic terms Stercorarius, Coprotheres, and Lestris have been applied, either to the species collectively or to the three divisions into which they have been separated; but, for myself, I prefer to keep them under one appellation.

The Great Skua is the solitary wanderer which visits the seas on both sides of the Line-the great brown bird seen by all voyagers who round the Capes of Good Hope and Horn-the Cape-Hen of the sealers, the Port-Egmont Hen of Hawksbury's and Cook's Voyages. I have stated that this bird is found on both sides of the Equator; at the same time I am aware that the birds of this form frequenting the southern hemisphere have been considered and characterized as distinct, under the name of Stercorarius antarcticus; but my own opinion is, that the birds of both hemispheres are referable to one and the same species.

The Great Skua is unknown in Greenland, but, according to Mr. Alfred Newton, is pretty common along the coasts of Iceland, and occasionally breeds some distance inland. Faber says it is resident, and names four breeding-places in the south-an island in the OElfusá, a sandy plain opposite the Vestmanneyjar, and the dunes of Skeiðarásanґr and Breiðamerkr. Dr. Krüper saw it in the north in summer-time; so that it probably breeds there also. In Scandinavia it is accounted rare, and it is very doubtful if it breeds in any part of the country. Mr. Newton does not recollect seeing the bird more than once during three voyages along the coast of Norway. It is not found in Spitsbergen; and though Von Baer includes it in his list of the birds of Nova Zembla, I am disposed to think the information is erroneous. It is utterly unknown on the coast of Siberia. Strange to say, Professor Baird's 'List of American Birds' gives the western or Californian coast only as the habitat of the bird in that country. In all the situations abovementioned, whether the bird be at sea or on the grass-covered bleak hills of the islands upon which it breeds, its presence is soon made known by its daring spirit. During the breeding-season, it is said that every animal is savagely attacked that approaches too near its nest, and that the Eagle and the Great Gull speedily scurry away out of distance, should they have ventured within its precincts.

"The Skua," says Macgillivray, "has much of the aquiline character, although it is not known to pounce on its prey and carry it off in its claws. On the other hand, it bears a great resemblance to the Gulls both in form and habits, keeping its body horizontal when standing, walking, and running with quick steps, and having a light and buoyant flight, more rapid and direct, however, than that of the Gulls. Its voice is sharp and shrill, and it is from the resemblance of its cry to that of the word skua or skui that it obtains its popular name. Dr. Edmonston informs me that 'the Skua has now become rare in Shetland, in consequence of proprietors permitting rapacious bird-collectors to shoot them indiscriminately during the breeding-season. In Unst there is only one locality frequented by them, and in all the country there are not more than four or five. In the one alluded to, the colony had been reduced to a single pair some years ago; since then it has been efficiently protected, and now it reckons more than ten pairs. This is, I suppose, the most northern preserve in Great Britain, and as such, perhaps, deserves to be recorded. The Skua is hardy and easily tamed. In captivity he is gentle and affectionate, and will feed on almost anything. When offended, he raises his wings and yelps in the manner of the Eagle; but his bearing is much more dignified and magnanimous. The bird remains with us during summer.'"

The Rev. Mr. Low gives the following account of the Skua as seen on the island of Foula, to the westward of the Shetland Isles :- “As I approached the summits of the high mountains, I came near the Skua's quarters, which are affixed on the very peaks. I no sooner drew near than I was attacked with such great fury, that every one who was with me, as well as myself, were obliged to do him obeisance at every 
stroke. He beat my dog entirely out of the pit, insomuch that he was obliged to run among our legs for shelter, and could not be forced out again; for although Bonxie, as the bird is called, had some respect for us while we kept together, on him he had no mercy; every whip he fetched him made his own wings crack, and the dog crouch into the hollows of the moor, until we came up and relieved him. I followed one of them to some distance from the rest of my party, and received some rude salutes for my imprudence from three of these birds, which made at me with the utmost rage. I defended myself the best way I conld with my gun, fired several times at them; but, as none dropped, the report did not startle them in the least, but rather seemed to enrage them the more. When the inhabitants are looking after their sheep on the hills, the Skua often attacks them in such a manner that they are obliged to defend themselves with their cudgels held above their heads, on which it often kills itself." It has a hoarse and strong cry, and lives much in the manner of the Parasitic Gull, attacking the larger kinds of Gulls as the other does the smaller, but never meddles with birds to destroy them, nor attacks the lambs on the island, but, in its opposition to all formidable intruders, protects them from the Eagle, who does not venture to prey there during the breedingseason. In gratitude for its services, it was protected by a penalty of sixteen shillings and eight-pence for every individual shot; and when met with at sea by the fishermen, it always had a share of whatever fish might be in the boat.

Captain Vetch, in his account of this species, published in the fourth volume of the 'Memoirs of the Wernerian Society,' says, "The Bonxie or Skua-Gull breeds, I believe, in the British Islands only in Shetland, and there only on the three highest hills-Snuke in Foula, Ronas, and Saxafiord. On Foula it seems to have taken exclusive possession of the Snuke, where it generally breeds at a height of 1300 feet, and nowhere else. It is easily tamed, and, I understand, is a very docile bird. I often observed it walking about within a few yards of the tent, and without any apparent fear ; when, however, its nest is approached, it shows a determination to defend its possession with its life. Ravens, Eagles, Hawks, or other birds are soon driven from the territory it inhabits. On nearing the nest, an attack instantly commences; male and female in rapid succession descend from a considerable height, with a velocity and noise truly startling; horses, cattle, and sheep are immediately put to flight, and receive no intermission of attack till driven far from the nest; and if man, bent on sinister purposes, continues to brave the Bonxie's fury, he seldom accomplishes his aim without carrying away marks of war. The nest is a mere concavity in the ground; the number of eggs, two ; the month of breeding, July. The young bird is a nimble, gallant little animal, and almost as soon as hatched leaves the nest. On the approach of danger, he secretes himself in holes or behind stones with great art, and, when captured, makes a sbow of defence that is quite amusing. The number of these birds that annually breed at Foula probably does not exceed thirty pairs."

In 'Some Observations on the Birds of the Faroe Islands,' by the late John Wolley, Esq., that gentleman says, "In the only two spots where the Great Skua now breeds in the British Islands, it is preserved only by the utmost vigilance of the proprietors, one of whom, Mr. Edmonston, has succeeded in recovering the stock, after it had been reduced to a single pair, in Unst. But in Faroe its breeding-places are numerous, though its preservation demands great self-control on the part of the people, for its attacks upon anyone approaching its nest are most irritating. Its blows are aimed at the head, with the full momentum of the bird's body; and it returns again with the most steady intrepidity imaginable. The protection afforded to it lasts only during good behaviour; when a colony is becoming too large some of them are apt to begin to attack lambs; they are then doomed to the infliction of a battue, which is supposed to act as a warning to the survivors for some years to come. It is said that only a few individuals acquire this bad habit-just as in the Scottish Highlands it is a single fox or eagle which gets into the way of carrying off lambs, but which evil-disposed one gives a bad name to, and is the death of, many of its innocent brethren.

"The Skua is one of the birds of which a certain number of heads is required to be given in by every inhabitant annually, which reminds one of the mode in which Eghert endeavoured to extirpate wolves in Britain. I do not know if this is now strictly enforced; but I have seen the people collect heads, when they had an opportunity, either of this bird or the Raven, or the Great Black-backed Gull-that is, when they were ready killed for them. I heard that several heads of the Hooded Crow or Richardson's Skua might be substituted for one of the larger birds. Skua is the Faroese name of the bird."

Mr. Dunn, who visited the Shetland Islands in 1831 and 1833, says " the nest is usually constructed amongst the heather or moss, the female mostly laying two eggs, but sometimes three." They are of an olive-brown, blotched with darker brown; and are two inches and nine lines long by two inches in breadth.

There is little difference in the external appearance of the two sexes; neither do the young differ from the adult, except in having the feathers more broadly margined with reddish brown.

The Plate represents the bird in its breeding-dress, somewhat smaller than the natural size. 


\section{$2 \mathrm{BHL}$ Biodiversity Heritage Library}

Gould, John. 1873. "Great Skua, Stercorarius catarrhactes [PI. 78]." The birds of Great Britain 5, -. https://doi.org/10.5962/p.324122.

View This Item Online: https://www.biodiversitylibrary.org/item/222497

DOI: https://doi.org/10.5962/p.324122

Permalink: https://www.biodiversitylibrary.org/partpdf/324122

\section{Holding Institution}

Smithsonian Libraries

\section{Sponsored by}

Biodiversity Heritage Library

\section{Copyright \& Reuse}

Copyright Status: Public domain. The BHL considers that this work is no longer under copyright protection.

This document was created from content at the Biodiversity Heritage Library, the world's largest open access digital library for biodiversity literature and archives. Visit BHL at https://www.biodiversitylibrary.org. 